\title{
Professional Embedding: The Inevitable Choice of Entrepreneurship Education in Local Colleges and Universities in the Era of Common Entrepreneurship
}

\author{
Li Jiang, Houchun Ding \\ Huanggang Normal College \\ Huanggang, Hubei, 438000
}

\begin{abstract}
This paper aims to examine the necessity and focus of the development of "full school entrepreneurship education" in local colleges and universities. We combed the literature, suggest the local colleges and universities in the entrepreneurial education on the long-standing ideological misunderstanding, highlighting that under strategic background of the "Widespread entrepreneurship and innovation", the necessity and urgency of developing "full - school entrepreneurial education" in local colleges and universities; It is pointed out that under the restriction of resource endowment, "professional embedding" is the inevitable choice for local colleges and universities to develop "whole school entrepreneurial education", and the establishment of entrepreneurship education curriculum reinforce the foundation of "education" of entrepreneurship education; and optimize the design of educational models, As well as from the point and face. To do the innovation and entrepreneurial activities of the daily and popularization is the current local college entrepreneurship education to achieve "professional embedded" focus.
\end{abstract}

Keywords-Public entrepreneurship; Local colleges and universities; Entrepreneurship education; Professional embedding

\section{INTRODUCTION}

With the arrival of "The era of common entrepreneurship ", the country's competitiveness is more and more dependent on the innovation of talents. The narrow connotation of "start-up enterprise" is replaced by "personalized and innovative talents", which has become the core pursuit of entrepreneurship education. Is to explore the "full entrepreneurial education" of the new mechanism, innovation and entrepreneurship throughout the process of personnel training to become the development of entrepreneurship education consensus [1]. This paper chooses the local colleges and universities to try to highlight the necessity and urgency of developing the "whole school entrepreneurship education" at the ideological level, and discuss how the local colleges and universities examine their own resource endowments and practical problems in the measures level, find the development of "Full Education "focus.

\section{WHAT DO COLLEGES AND UNIVERSITIES NEED TO DO? - TO CARRY OUT "SCHOOL-WIDE ENTREPRENEURSHIP EDUCATION"}

This question is essentially asking "what kind of people should be cultivated in colleges and universities," and "what kind of literacy should students have?" "Student core literacy" has also become one of the cutting edge and hot issues in China's education research in 2015 [2]. And in accordance with the US Department of Education, Microsoft, Cisco and other government agencies and enterprises jointly developed the "21st century skills framework" argument : "Learning and innovation skills" was placed in the first three areas of skills first. "The world is flat," the author Freeman will be divided into three stages of globalization process: 1.0 era (1492-1800) the driving force of globalization from the country; 2.0 era (1800-2000) - the driving force from the enterprise; 3.0 era (2000 to date) - the driving force from the individual. Therefore the individual culture is the direction of education reform, and independent spirit and free thought is the inevitable requirement of individualized training [3]. It can be seen that, in order to meet the challenge of changing times, the entrepreneurial education of colleges and universities has no doubt to serve the core demand of "innovative talents training". Cultivate "personalized, innovative talents" is the core pursuit of entrepreneurship education.

But for a long time, local colleges and universities have organized entrepreneurial education in the "narrow sense" at the ideological level, that is, combined with employment training, to provide educated people with much-needed skills and resources so that they can support themselves [4]. "Employment first", "entrepreneur-driven employment" and the like to a certain extent, reflects this concept, entrepreneurship education in the classroom teaching is very weak, and even long-term only a school-level elective course of the objective fact is this The result of a concept, which is essentially a misunderstanding of entrepreneurship education. The United States must maintain its political and economic leadership in the world and must see the entrepreneurial spirit is our core competitive advantage," said Karl J Schram, chairman of the Kaufman Foundation. China's colleges and universities to carry out the value orientation of entrepreneurship education, but also from the initial use of 
college students to solve the severe employment pressure, to create entrepreneurial economy for entrepreneurial talent. Entrepreneurship itself is only part of a small number of people things, "founder of the enterprise" is not the fundamental purpose of entrepreneurship education, "Widespread entrepreneurship and innovation " is the core of "universal innovation", "entrepreneurial spirit" is the core of entrepreneurship education [5].

In short, innovation and entrepreneurship education is the responsibility of the times, entrepreneurship education is a high-level quality education, but also a sound personality education, shoulder the social, educational and human development mission, to resolutely get rid of "founder business theory" and " Second classroom theory [6]". We must make innovation and entrepreneurship become the common pursuit of social and behavioral habits, colleges and universities should make innovation and entrepreneurship should become the university's culture and consciousness. To explore the "full entrepreneurial education" of the new mechanism, innovation and entrepreneurship throughout the entire process of personnel training in the "Widespread entrepreneurship and innovation "and the transformation of local colleges and universities in the context of the development of this situation is even more time to wait [7].

\section{HOW DO LOCAL COLLEGES AND UNIVERSITIES} IMPLEMENT "SCHOOL-WIDE ENTREPRENEURSHIP EDUCATION"? - PROFESSIONAL EMBEDDING

"The whole school of entrepreneurship education," the development of sufficient resource endowment as a support. Throughout the typical practice of the development of entrepreneurial education in colleges and universities ( Table 1) [9], the "deep focus mode" represented by Tsinghua University is a collection of technological innovation, technology commercialization and high-tech industry, which fully supports its "science and technology" and "geographical advantage", similar practices are "Shanghai University of Technology" [8]; "post entrepreneurial education model" as the representative of Wenzhou University, which is to make full use of the developed local enterprise resources, entrepreneurship education With the local economic resources closely together. And for many local colleges and universities, especially in the economically underdeveloped prefecture-level city of local colleges and universities, it is clear that the lack of such a resource endowment.

TABLE I. TYPICAL MODEL OF ENTREPRENEURSHIP EDUCATION IN CHINA

\begin{tabular}{|c|c|c|c|}
\hline $\begin{array}{l}\text { Development } \\
\text { model }\end{array}$ & $\begin{array}{l}\text { Representative } \\
\text { school }\end{array}$ & specific methods & Typical features \\
\hline $\begin{array}{l}\text { Depth focus on } \\
\text { education } \\
\text { model }\end{array}$ & $\begin{array}{l}\text { Tsinghua } \\
\text { University }\end{array}$ & $\begin{array}{l}\text { They set up China Entrepreneurship } \\
\text { Research Center, Technology } \\
\text { Innovation Research Center; } \\
\text { Set up more than } 10 \text { door series of } \\
\text { entrepreneurship; } \\
\text { Cooperation in the construction of } \\
\text { "Tsinghua - Berkeley Global } \\
\text { Technology Business Project"; } \\
\text { Relying on Zhongguancun's leading } \\
\text { technology enterprises }\end{array}$ & $\begin{array}{l}\text { Based on scientific } \\
\text { research advantages } \\
\text { Depth collection of } \\
\text { technological innovation, } \\
\text { technology } \\
\text { commercialization and } \\
\text { high-tech industry } \\
\text { situation }\end{array}$ \\
\hline $\begin{array}{l}\text { Classroom } \\
\text { expansion } \\
\text { education } \\
\text { model }\end{array}$ & $\begin{array}{l}\text { Renmin } \\
\text { University of } \\
\text { China }\end{array}$ & $\begin{array}{l}\text { "The first class" to open a series of } \\
\text { courses } \\
\text { "Second class" social practice and } \\
\text { social welfare living, business } \\
\text { education lectures and various } \\
\text { competitions }\end{array}$ & $\begin{array}{l}\text { Reform of classroom } \\
\text { teaching methods } \\
\text { Students choose their } \\
\text { own space }\end{array}$ \\
\hline $\begin{array}{l}\text { Entity } \\
\text { experience } \\
\text { education } \\
\text { model }\end{array}$ & $\begin{array}{l}\text { Heilongjiang } \\
\text { University }\end{array}$ & $\begin{array}{c}\text { Relying on college students } \\
\text { Entrepreneurship practice base } \\
\text { Open research laboratory surface } \\
\text { Set up business entities: such as student } \\
\text { supermarkets }\end{array}$ & $\begin{array}{l}\text { Integrate school } \\
\text { resources } \\
\text { Create entity } \\
\text { entrepreneurship } \\
\text { experience } \\
\end{array}$ \\
\hline $\begin{array}{l}\text { Post } \\
\text { entrepreneurial } \\
\text { education } \\
\text { model }\end{array}$ & $\begin{array}{l}\text { Wenzhou } \\
\text { University }\end{array}$ & $\begin{array}{l}\text { Set up an entrepreneurial talent training } \\
\text { college } \\
\text { Provide free business practice place } \\
\text { Construction of out - of - school } \\
\text { students' practice base }\end{array}$ & $\begin{array}{l}\text { Make full use of local } \\
\text { resources } \\
\text { Cultivate job awareness } \\
\text { and ability to guide }\end{array}$ \\
\hline
\end{tabular}

"Weak foundation and the lack of resources" in the past is to limit the local college entrepreneurship education development of the important reasons, has now become its development "school-wide entrepreneurial education" a major obstacle. Therefore, the local colleges and universities focus on the truth, according to local conditions to choose their own business education development model. With the "People's University of China" as the representative of the "classroom 
expansion of education model", pay attention to "the first classroom" to open a series of courses, "the second classroom" extensive social practice, social welfare, entrepreneurship education lectures and various competitions; "Entity experience education model", represented by "Heilongjiang University", develops entrepreneurial education (see Table 1) by relying on the entity practice base of university students and the establishment of business entities (such as student supermarkets). These two models do not separate entrepreneurial education from professional education and are not considered as "the second class". In all aspects of professional regular teaching activities, the embedding of "entrepreneurial spirit cultivation" and "transmission of entrepreneurial knowledge" That is, "professional embedded"), and from the overall highlight of the professional differences in nature, so that entrepreneurship education courses and activities of the diversification and differentiation to meet the innovative entrepreneurship of multidisciplinary knowledge of open, personalized integration needs, more suitable In the lack of technology research and development and technological transformation advantages, as well as the lack of developed local entrepreneurship economy to support the local colleges and universities to carry out "full school entrepreneurship education."

\section{LOCAL COLLEGES AND UNIVERSITIES THROUGH THE} "PROFESSIONAL EMBEDDED" SHOULD FOCUS ON WHAT ASPECTS TO DEVELOP "FULL SCHOOL ENTREPRENEURSHIP EDUCATION"?

\section{A. The establishment of entrepreneurship education courses, reinforce the foundation of "education" of entrepreneurship education}

Porson Business School, Massachusetts Institute of Technology Sloan School of Business, etc. is the 2011 "Financial Times" global MBA ranking in the top ten schools of entrepreneurship, their entrepreneurial education courses more, rich category [10]. The The study shows that as of 2013, there are only 41 colleges and universities in China, only 41 colleges and universities set up business-related courses, many places colleges and universities only set up a "business management" or "college students employment and entrepreneurship guidance" course, the United States has 1600 universities or more have provided more than 2,200 entrepreneurship courses [9]. Therefore, we must integrate the entrepreneurial education into the professional education, the development of "whole school entrepreneurship education", we must first strengthen the curriculum research, increase the number of entrepreneurship education courses, change the local college education entrepreneurship marginalization of the status quo. Specifically, the first, each college in addition to the general education curriculum, combined with professional characteristics, set up 3-5 subjects dedicated to innovative entrepreneurship education professional courses, and into the school entrepreneurship education courses elective areas for the Students elective; second, to meet the business needs of business management knowledge, the school's business school or School of Economics and Management should be oriented to students from the production and marketing, property and other aspects of the refinement of the establishment of entrepreneurial management skills courses 6-10, and incorporated into the school Entrepreneurship education courses elective areas for students to elect. Third, make full use of information technology development, the school can have plans to increase the network "Mu class" in the form of teaching resources, but the premise is to refine the curriculum, the implementation of the whole teaching guidance, in order to enhance entrepreneurship education "The number of "effective courses".

\section{B. Optimize the design of educational models, and guide students' personality development}

The increase in the number of courses is the foundation, but the effectiveness of the course depends on the design of entrepreneurship education model to provide assurance. In general, it is necessary to strengthen the innovation and entrepreneurship education on the basis of the combination of innovation and entrepreneurship education orientation, for different professional, different background students to design and provide a "step by step" path, so planning, by the shallow To the depth of the school-oriented, full consideration of the individual needs of students of entrepreneurship education. On this point, you can follow the practice of Tsinghua University in Taiwan [11] should do:

First, colleges and universities should strengthen the design of general education curriculum, through the breadth and depth of knowledge integration and planning for students to provide a guide to the development of personality. They set up a body similar to the "Liberal Education Center", specializing in how to nurture innovative talents into the "general education" level, the formation of "core knowledge compulsory course" and "advanced general elective courses" The architecture, In addition, each level of the curriculum, according to the local colleges and universities to set their own professional situation, do a good job of knowledge breadth and depth of integration and planning to form similar to the way of thinking, life exploration, art and literature, science and technology and society (Social science, education, research, information dissemination, economy) and people in the field of social sciences (basic science; applied science; science and technology and society), social sciences The different categories of "dimensions" and "categories" are to be integrated into a systematic "general curriculum map" to General education level began to guide students to find personalized development path.

Second, colleges and universities should build a diversified study channel, for the students' personality and comprehensive development to provide convenience. On the basis of the excellent curriculum system and the rich content of the course group, Taiwan Tsinghua University has given a variety of disciplines, majoring in major, minor, credit and other forms of study channels, students in line with the relevant conditions on the basis of , According to their own needs to choose the form of study, to study their interest in the professional, to guide their own professional knowledge to the depth of development, which fully protect the students on the basis of maintaining the personality to help students develop in an all-round way. In addition, even in the field of specialization, the school and the college give students a real sense of "self-elective", and students are free to take courses in the course of each semester 
(some courses are based on pre-course Requirements), audition is not satisfied with the deadline can also be withdrawn within the prescribed period, as long as the final number of schools to achieve the required credits, students can flexibly arrange each semester of the learning process. Schools and even encourage students to "credits each other" outside the school elective related courses. This full autonomy to ensure that students personalized development and the concept of comprehensive development, in fact, is fundamentally expected to retain the personality and creativity of students is to implement the best embodiment of innovative entrepreneurship education.

Third, the establishment of a separate entrepreneurial credit credits, deepen the depth of entrepreneurship education. If the "narrow sense of entrepreneurship" to see the problem. Tsinghua University, Taiwan also set up an "Innovation and Entrepreneurship Program" and "Innovative Design Program", which directly points to "cultivating students' spirit of innovation and entrepreneurship. Go to business ". Among them, the former given the "basic curriculum" and "supportive course" at least 15 credits of the study plan, and, each "subclass" under the course, but also with the "group" concept for students to provide a Fully docked its professional characteristics, rich and detailed courses, the number of courses to reach more than 70 doors. The latter also need at least 15 credits, of which the core course at least 6 credits.

\section{By the point and surface, so that innovation and business activities of the daily and universal}

Innovation and entrepreneurial activities as a creative and entrepreneurial "knowledge" transformation of the necessary links, of course, should be attention and development, in " The era of common entrepreneurship ", the school development "school-wide entrepreneurship education" should be innovative entrepreneurship activities, so " By the point and face, to enhance student participation and participation rate to this end:

First, the formation of active organization and promotion of effective mechanisms. We should change the status quo of "full-time teacher responsibility system" in the subject professional competition, and play the role of faculty function in the application, publicity, organization and other aspects of the activity, and position the professional teacher as "the counselor of professional knowledge" Of the organization, can be widely publicized, can attract students to participate in the basic conditions.

Second, colleges and universities should be "a professional event and a fine event" construction. Each professional to longterm adhere to the development of at least one subject professional event, if the provincial and national level-related events docking, the establishment of "school race - province race - national race" effective link mechanism, the event "professional Knowledge counseling "part of the professional (faculties) are responsible for the relevant teachers. Can not be compared with the existing provincial, national events, but also to develop the professional, to accept the school's "one year race" or "one semester race" working mechanism. On this basis, the college preferred focus on one or two "boutique tournament", and gradually formed a broad student base, participate in active and rich culture of the "brand event."
Third, innovation and entrepreneurial activities of the "daily". For the "whole school entrepreneurship education" innovative business activities, we must be able to attract students' interest, enhance the activities can participate, which requires outside the professional competition, to carry out "daily" innovation and entrepreneurship activities. Where the daily activities, one refers to the activities of the shorter cycle, faster, more categories, more flexible form, the second is the theme of activities can be divorced from professional restrictions, as far as possible around the interests of students, students have realistic feelings of "Micro theme "unfolds. For example: the "Entrepreneurial Design Competition" and other annual events, set up a "monthly creative game", so that students can cut into these activities at any time, to maintain thinking on the "uninterrupted"; can also set " How to make your dormitory more warm", "How to make the campus more clean", "How to prevent telecommunications fraud" and many other students are closely related to life in school, students can easily understand, Or search for hot topics for students to "competitive creative activities", these activities can even be "Weekly Challenge" form, the school can set up a "Weekly Creative Award" awards to encourage students.

\section{CONCLUSION}

In the context of "The era of common entrepreneurship ", local colleges and universities should get rid of the misunderstanding of the development of entrepreneurship education and carry out "all-school entrepreneurship education". To this end, local colleges and universities need to face their own development base and resource endowment, To the whole process of personnel training, take the "professional embedded" development path, and the addition of entrepreneurship education courses, reinforce the foundation of "education" of entrepreneurship education; optimize the design of educational models to guide students' personality development and innovation and entrepreneurial activities of the daily and universal The focus of the current work.

\section{ACKNOWLEDGMENT}

Fund Project: Hubei Province Education Science Planning 2016 degree project (2016GA036), Huanggang Normal University teaching and research project (2015CE31), Huanggang Normal College 2016 annual development of the practice of brand building project (zxfz2016B034).

\section{REFERENCES}

[1] Wang Yiming. "The era of common entrepreneurship"Development of the Communist Youth League [J]. Journal of Guangdong Youth Vocational College, 2015 (2): 11-15.

[2] Education Research Editorial Board 2015 China Education Research Frontier and Hot Issues Annual Report [J]. Education Research, 2016 (02): 4-17.

[3] Peking University Institute of Education and Economics Professor Yue Changjun. Public entrepreneurship, education first [N]. Social Sciences.

[4] Ma Xiaohui. Entrepreneurship education ecological transformation and realization of the way [J]. Education Development Research, 2013 (19): $59-62$.

[5] Xu Xiaozhou, Zhang Min. Entrepreneurial education concept change and strategic choice [J]. Education Research, 2012 (05): 64-68. 
[6] Wu Jinqiu. The goal and function of entrepreneurship education [J] .Hebei Higher Education Research, 2004 (11): 99-101.

[7] Wang Yiming. "Public times" Communist Youth League institutions of entrepreneurship education [J] .Guangdong Youth Vocational College, 2015 (2): 11-15.

[8] Huang Zhaoxin. Local colleges and universities entrepreneurial education transformation and development - based on the comparative analysis of two institutions [J]. Higher Engineering Education Research, 2014 (06): 141-146.
[9] Li Weiming, Li Chunyan, Du Xiaohua. China's college education ten years: evolution, problems and system construction [J]. Education Research, 2013 (06): 42-51.

[10] Wang Jingjing, Yao Fei, Zhou Xin, etc. The world famous business school entrepreneurship education comparison and its enlightenment [J]. Higher Education Research, 2011 (07): 80-86.

[11] "credits" introduction [EB / OL], Tsinghua University, Taiwan "school group" website, http://curricul.web.nthu.edu.tw/files/13-1073-11644.php; General Information "[EB / OL], Tsinghua University, Taiwan" General Education Center "website, http://cge.gec.nthu.edu.tw/course.html. 